\title{
LANGUAGE, PLURALITY, AND MINORITIES IN EUROPE
}

\begin{abstract}
Мањинска политика и језичка мањинска политика засноване су на европској идеологији о националној држави и држави-нацији, концепту који произлази из племенске дихотомије између сопственог и другог који се тумачи као хомогеност између људи, њихове територије и културе. Ово последње, пре свега, симболизује заједнички језик. Сходно томе, мањине себе доживљавају као различите у односу на већину. С друге стране, ово отуђење доводи до тога да мањина себе схвата као другу нацију са другим језиком, којом доминира држава-нација са доминантним језиком. У овом контексту европска језичка различитост мора бити окарактерисана као искључива и као она која влада по принципу доминације. Међутим, овај социополитички приступ који заговара и наглашава хомогеност, у супротности је са плуралистичком реалношћу људске културе. Стога, политике и мере за заштиту етнолингвистичке разноврсности треба да буду засноване на идеологији, или пак на политици различитости.
\end{abstract}

Кључне речи: језичка мањинска политика, национална држава и држава-нација, европска идеологија, принцип доминације и хомогености насупрот политици различитости.

Minority politics and the linguistic diversity of Europe are intrinsically linked with the concept of the nation. The underlying principle of the European ideology of both the nation-state and the state-nation is the holy trinity of people, land and language (Fishman 1972). The role of language in this context seems to be deeply rooted in the collective subconscious of our society.

One ingredient of the holy trinity (holy people, holy land, holy language), language has been regarded as a defining characteristic of a nationality, within the sphere of the Judeo-Christian tradition, since Bible days.

(Fishman 1989: 274)

The reference to biblical times localizes the holy trinity in the tribal context of the homogeneity of people, land, and language. Together with 
a common cultural heritage that is encoded in the respective language this homogeneity constitutes the language-ethnicity link. The fatal or rather lethal effects of this link are also documented in the Bible. It is the widely known and often cited story from the Book of Judges about the wrong pronunciation of the word Shibboleth that caused the death of " 42,000 descendants of Ephraim".

The descendants of Gilead seized control of the Jordan River's fords along the border of Ephraim's territory. Later on, when any fugitive from Ephraim asked them, "Let me cross over," the men from Gilead would ask him, "Are you an Ephraimite?" If he said "No," they would order him, "Pronounce the word 'Shibboleth' right now." If he said "Sibboleth," not being able to pronounce it correctly, they would seize him and slaughter him there at the fords of the Jordan River. During those days, 42,000 descendants of Ephraim died that way.

(Judges 12/5)

Their common descent characterizes the Ephraimites as a kin group with a territory and a language. In this tribal manifestation of the holy trinity, language awareness is rooted in the dichotomy between the own and the other. The own language is a basic feature of identity, whereas the other language constitutes this identity by its diversity. For an individual, the link between their kin group, the respective territory, and their language is first of all emotionally rooted. The transformation of this principle into modernity may be outlined as follows.

\section{Historical Development}

During the Renaissance, Latin loses its universal status, and the socalled vernacular languages gain more and more importance in culture and administration. The Peace of Westphalia, that ends the Thirty Years' War in 1648 , links a territory and its people with a sovereign and his religion. As a result, the concept of the sovereign state within clearly defined boundaries becomes central to the political order. Furthermore, the relation between the territory of a state and its inhabitants gains importance. Thus, awareness of the necessity of a common language also rises.

Philosophy develops the idea of nationality as the relationship be- 
tween an individual and a state. According to Anderson (1983) the nation is the "imagined community" of these individuals. In the $18^{\text {th }}$ century, the relation between a nation and its language is regarded as God-given. The spirit of a nation is thought to materialise in its mother tongue. Languages are perceived as natural divides between nations. As a consequence, national consciousness develops among the populations of the monarchies of Europe. In parallel, the bourgeoisie increases its economic power and, as a result, its political influence. These and other developments, as well as the resulting problems and tensions, culminate in the French Revolution of 1789 to 1799 . One of the ideals of the French Revolution is the linkage between a people as the sovereign of a territory and a language. Thus, the holy trinity is re-established as an ideology of modern Europe. The tribal homogeneity of people, land and language, changed into the national homogeneity of people, state, and language. A tribal concept of territoriality and linguistic identification has been normalised and modernised at another level of social cohesion.

Although this modern version of the ideology is functionally based, it is also emotionally loaded. It is evident that a state needs an official language that functions in public formal domains. It guarantees mutual understanding in the contact between the state and its citizens. The very core of the emotional aspect is still centred round the ethnicity based idea of the folk spirit, the German Volksgeist. This idea roots the concept of a nation in ethnicity. Language is believed to be the manifestation of ethnic identity in the national spirit. This belief and connected concepts are deeply rooted in the subconscious of any European nation. Individually the link between nation, territory, and language is still emotionally coded. The resulting possible collective mystifications always have the potential to turn this ideology of the ethnic nation-state into a lethal weapon.

The internal unification of European states is based upon the outlined ideology and the associated idea of a state-nation. A state-nation is defined by an imagined common ethnic ancestry, shared cultural heritage that often includes a common religion, and a common language. Consequently, unification is always understood as homogenisation on the basis of the system of values of the state-nation. In the course of linguistic unification efforts, different groups of speakers are subjugated under the dominant language 
of a state-nation. The administrative necessity of mutual understanding in public communication is the utilitarian aspect of this process. Languages are banned from official use, and their speakers excluded from political life unless they use the dominant language. Functional bilingualism would fully suffice this administrative aspect of linguistic unification. However, this is only one side of enforced homogenisation. The other side is rooted in the initially mentioned dichotomy between the own and the other. On this background speakers of other languages are excluded, discriminated, and persecuted. The bandwidth of measures ranges from corporal punishment of pupils and language prohibition on a legal level to the enforced relocation of groups of speakers. Such measures contribute to the assimilatory pressure that has shaped the linguistic landscape of the official Europe of today. The outlined development of the European ideology of the ethnic nation-state may be summarised into three steps.

- the $18^{\text {in }}$ century sees its development,

- the $19^{\text {i }}$ century sees its implementation,

- the $20^{\mathrm{m}}$ century sees its perversion during fascism.

The 20th century also sees the application of this ideology in the post-colonial context during the foundation of nation-states outside Europe. The resulting negative implications and repercussions hamper the development of most of these countries to the present day.

One of the indirect consequences of the political and humanitarian disasters during the first half of the 20th century is the democratisation of the ideology. The concept of the ethnic nation-state develops into the concept of the civic nation-state. Compared to the citizens of an ethnic nationstate, which are idealized as members of one homogeneous state-nation, the definition of citizenship in a civic nation-state is not inevitably ethnicity based. Although an ethnic group that acts like a state-nation dominates in most civic nation-states, the possibility for the integration of members of other ethnic groups as citizens on an equal basis is legally guaranteed. It is this aspect of sociopolitical development that initiates the transformation of the official linguistic diversity of Europe from the simple addition of national languages to the consideration of all indigenous languages. It is only towards the end of the 20th century that linguistic diversity becomes part of the European self-perception.

The sociopolitical process outlined so far starts with the link between 
a kin group and its language on a tribal territory. It continues with the transformation into a link between a nation and its language on the state level. In the next step, it develops the additional linkage between language and diversity in the territory of a state and beyond.

A key factor contributing to the last development is the organisation of European states on a supranational level in the context of the Council of Europe. Its activities have resulted in standards and instruments to secure human rights and democracy and to facilitate cooperation between European countries.

\section{Protection of Minority Languages}

Languages and linguistic rights fall within the competence and responsibility of three monitoring bodies at the Council of Europe:

- The European Commission against Racism and Intolerance (ECRI) is a human rights body which monitors problems of racism, xenophobia, antisemitism, intolerance and discrimination on grounds such as "race", national/ethnic origin, colour, citizenship, religion and language. ECRI was adopted by the Committee of Ministers of the Council of Europe in 1993. First reports on the situation in member states were published in 1997. ECRI has been recognised by all 47 member states.

- The Framework Convention for the Protection of National Minorities (FCNM), is designed to protect the rights of persons belonging to national minorities. The FCNM was adopted in 1994, it entered into force in 1998 and has been ratified by 39 of 47 member states.

- The European Charter for Regional or Minority Languages (ECRML) is a convention designed on the one hand to protect and promote regional and minority languages as a threatened aspect of Europe's cultural heritage and on the other hand to enable speakers of a regional or minority language to use it in private and public life. Its overriding purpose is cultural. The Charter was adopted in 1992. It entered into force in 1998 and 25 of the 47 member states have ratified it so far.

Despite the conflicts in the aftermath of the communist era, the outgoing $20^{\text {th }}$ century was characterised by a positive attitude towards the idea 
of European integration. This positive political climate supports, among others, the decade-long efforts and demands of Western European minorities. Their struggle for emancipation is the starting point and the main motivation for minority protection in Europe. The legal recognition of indigenous communities as national minorities is characteristic of civic nation-states. With the weakening of radical nationalism on the state level, it has become possible to reconcile the sovereignty of a civic nation-state with the autonomy of an ethnic group. A symptom of how difficult it has been to reach agreement at the European level, is the absence of a definition of national minority in the Framework Convention. Another symptom is the level of ratification of these instruments. The more language is in the focus of attention, and the more specific the measures of protection are formulated, the less state parties are specified. ECRI is a common instrument of all 47 member states, the Framework Convention has been ratified by 39 , the Charter only by 25 state parties.

The Charter is the main legal instrument for the protection of the linguistic diversity of Europe. Although, or better because the issue of minority languages is highly political its overriding purpose has been defined as cultural. The Charter protects and promotes languages as integral part of the wealth and diversity of Europe's cultural heritage. Currently, roughly 70 languages are protected under the Charter. In Western European and Scandinavian countries, an average of five languages is protected. It was the enlargement of the Council of Europe in the 1990s and the ratifications by Central and Eastern European countries that raised the numbers. The countries with the highest numbers of languages protected are:

- Poland and Serbia with 15 languages,

- Bosnia and Herzegovina with 17 languages,

- Ukraine with 18 languages,

- Romania with 20 languages.

Languages protected under the Charter range from Swedish as a co-official language in Finland to Cornish as a minority language in the process of revitalisation. Per definition, the Charter covers three types of languages:

- regional or minority languages,

- non territorial languages,

- less widely used official languages. 
The latter designation is used in the ratification of the Charter by Switzerland for Italian and Romansh. It also applies to

- Basque in the Autonomous Community of the Basque Country and the Basque-speaking regions of the neighbouring Chartered Community of Navarre in the Kingdom of Spain,

- Welsh as an official language of Wales as part of the United Kingdom,

- West Frisian, in the province of Fryslân in the Kingdom of the Netherlands.

These three languages or rather their representatives have been at the very core of the initiatives for emancipation mentioned above. Thus, it is no coincidence that a special label applies to their specific situation. They also fulfil the criteria of indigenousness, cultural heritage, and territoriality. One is tempted to say that these languages are prototypical for the linguistic diversity of Europe.

Territoriality as a basic principle in the definition of a minority language makes it necessary to establish the category of non-territorial languages. It allows the protection of languages like Yiddish under the Charter. From a Western European perspective, this category also applies to Romani. In other parts of Europe Romani fully complies with the territorial definition of the Charter. There are "geographical areas in which" Romani "is the mode of expression of a number of people justifying the adoption of various protective and promotional measures". However, another aspect of the Western European perspective inseparably identifies Romani with non-territorial. The allegedly political correct designation of Roma and Travellers erroneously insinuates a common nomadic way of life of the Romani people and incorrectly confirms the non-territorial character of their language. By contrast, Romani is only three times labelled a nonterritorial language in ratification documents. Nevertheless, it is treated as a non-territorial language in the reporting and monitoring processes. In total, the designation is explicitly used by four countries for six languages:

- Armenian by Cyprus and Poland,

- Hebrew by Poland,

- Karaim by Poland,

- Karelian by Finland,

- Romani by Finland, Poland, and Sweden,

- Yiddish by Poland and Sweden. 
The vast majority of languages protected under the Charter carry the designation of a regional or minority language. Although this phrase suggests a difference in status between two types, in most cases no distinction is made. One of the few exceptions is the ratification by Germany.

Minority languages within the meaning of the European Charter for Regional or Minority Languages in the Federal Republic of Germany shall be the Danish, Upper Sorbian, Lower Sorbian, North Frisian and Sater Frisian languages and the Romany language of the German Sinti and Roma; a regional language within the meaning of the Charter in the Federal Republic shall be the Low German language.

Some ratification documents use the designation collectively:

Sami, Finnish and Meänkieli are regional or minority languages in Sweden ... ... the Saami language which is a regional or minority language in Finland ...

Some ratification documents exclusively use the designation minority language:

Denmark declares that it will apply the following provisions of Part III of the Charter to the German minority language in Southern Jutland ... Austria declares that minority languages within the meaning of the Charter in the Republic of Austria shall be the Burgenl and croatian, the Slovenian, the Hungarian, the Czech, the Slovakian languages and the Romany language of the Austrian Roma minority.

In other ratification documents, the protected languages are not labelled at all. One ratification uses three designations for the same group of languages: minority language, regional or minority language, and national minority language. Maybe this is a shortcoming of the translation into English. But it fits the overall picture of an incoherent use of designations for the languages of ethnic minorities.

The common feature of all languages protected under the Charter is their status as an official language in the respective country. A small number of protected languages have co-official functions in a clearly defined political and geographical unit of the territory of a state. Non-territorial languages are functionally restricted and remain geographically undefined. 
In the vast majority of cases, languages protected under the Charter are functionally and geographically restricted.

As indicated, the protection of indigenous stateless languages like the Frisian, the Sami and the Sorbian languages was the main reason for the provision of the Charter. These languages are understood as part of the threatened cultural heritage of Europe. As not all countries of Europe have ratified the Charter so far, some of these languages are still outside its protection. Nevertheless, more than $60 \%$ of the languages covered by the Charter fall under the definition of a stateless indigenous language of Europe. Each of the other less than $40 \%$ or 25 languages functions as an official language of a state and is also protected under the Charter in other, above all, neighbouring countries.

16 of these languages are official in countries that have ratified the Charter. Eight are official in countries without ratification. One, Belarusian, is officially used in a country without membership to the Council of Europe.

On this background, the overriding cultural purpose of the Charter is seriously called into question. If the government of a country perceives or declares itself as the protective power of speech communities of varieties of its official language that are spoken in the territories of other countries, this has an important political aspect. Such situations range from reciprocal protection of cross-border languages to possible confrontations.

The situation in the Danish-German border region is characterised as an unproblematic and more or less harmonious case of cross-border recognition. Both German in Southern Jutland and Danish in SchleswigHolstein are protected as minority languages by the legislation of each country and, consequently, also under the Charter.

The Austrian minority languages Czech, Hungarian, Slovak and Slovene are official in the respective successor states of the Austro-Hungarian Empire. Minority speakers in Austria receive various kinds of support from these countries. The situation of the minorities is addressed in bilateral contacts between Austria and its neighbours. Furthermore, minorities and their languages are an issue in the political discourse of the countries. Thus, an exclusive definition of these languages as part of the ethnolinguistic cultural heritage of Austria would be insufficient. 
It has to be added that Austria has declared itself as the protective power of the German-speaking population of Alto-Adige or rather South Tyrol. The resulting intensive contacts with Italy were in no way free of conflicts in the past. However, the political negotiations have contributed to the co-official status of German in the Italian Autonomous Province of Alto-Adige.

Hungary plays an active role as the kin state of speakers of Hungarian in neighbouring countries. The territories where the Hungarian-speaking communities live were part of the Kingdom of Hungary during the AustroHungarian Empire. Active protectionism across national boundaries often creates a feeling of insecurity and uncertainty amongst the population. Consequently, it seriously affects social cohesion between minority groups and the majority. As an intervention into internal affairs, it also jeopardises bilateral relationships.

The role of Romania as a protective power seems to be based on a politicised nationalist view of a linguistic-genetic relationship. There is the idea that Romanian is a macrolanguage with four varieties: Daco-, Istro-, Macedo-, Megleno-Romanian. Daco-Romanian subsumes Romanian and Moldovan. Istro-Romanian varieties are or were spoken on the Istrian peninsula. Macedo-Romanian subsumes varieties known as Aromunian and Vlach. Megleno-Romanian subsumes varieties labelled Vlăhește by its speakers and Meglenitic by linguists. Additionally Boyash is protected under the Romanian linguistic-political umbrella. Linguistically the varieties of Boyash are based on old Romanian dialects. They are spoken by Romani communities outside of Romania, in Croatia, Hungary, Serbia, etc. Apart of the fact that Boyash varieties are significantly shaped by their contact languages, they are perceived by the speakers as their languages. Thus, Boyash is treated as a language, not only in the context of the Charter. Nevertheless, as all of these linguistic varieties are related to Romanian, the genetic relationship is used to justify the role as a protective power.

Turkey plays a similar role as protective power for Turkic-speaking minorities in the Balkans, the Black Sea Region and the Caucasus Region.

Kin state policy must not be deemed as negative per se. If such a role is negotiated and bilaterally approved, it might even contribute to the maintenance of a minority language. But the more unilateral and biased 
the activities of kin state protection are pursued the more critical and suspicious the government of the other country will react. The more nationalist propaganda is involved, the higher is the potential for conflicts.

Conflicts may also result from situations when a former dominant language with a nationalist kin state is in the process of transition to a minority language. This is the case with Russian in the Baltic States. Lithuania has a minority of 8\% Russian speakers. In Latvia as well as in Estonia one-third of the population speaks Russian. The three countries have ratified the Framework Convention but not the Charter. A precondition for the ratification is the clarification of the status and role of Russian that is in a phase of transition. The same applies for its speakers. They are in a transition from Russians living in a foreign country to Russian Estonians, Latvians and Lithuanians. This is the positive projection into the future. Nationalism on both sides, the Baltic States and Russia, has the potential to radicalise the situation and make the outlined development impossible. The less nationalism is involved, the easier the necessary changes will happen.

Macedonia is in a similar situation. It ratified the Framework Convention as early as 1997 but not the Charter. The ratification would require the clarification of the status of Albanian. There are, among others, two options: To establish Albanian as an official language at the state level or to declare it a co-official language in the Albanian-speaking territories under the protection of the Charter. Currently, both options are politically highly sensitive and a ratification is most probably no option for the near future.

This short outline of political involvement in minority language issues indicates how idealistic, sensitive, and fragile, not to say quixotic it is to define linguistic diversity as a primarily cultural matter. Superficially, it works fairly well with indigenous stateless languages in the context of civic nation-states. To include Sami speakers on an equal basis as citizens with another cultural heritage and language in Finland, Norway and Sweden has no negative implications at all. On the contrary, it symbolises honest restitution for the atrocities the Sami people suffered over a long period of enforced assimilation. Ladin is officially recognised in more than 50 municipalities in the Italian provinces of Alto-Adige, Trentino, and Belluno. This definitely can be seen as the protection of a minority language as 
part of the threatened cultural heritage of Europe. The same applies for the official recognition of languages like Ladino in Bosnia and Herzegovina or Karaim in Poland and Ukraine. Valuing and protecting such languages is an expression of the integrative aspect of European linguistic diversity.

Demographically speaking, none of these languages has a significant number of speakers. The highest percentage of an ethnic group is a little over $1 \%$ of the Sami population of Norway. But this is no benchmark for the number of speakers. About the total number of the population in the respective countries, all these groups amount to far less than $1 \%$. The percentages for Karaim and Ladino are microscopic. Furthermore, none of the languages and respectively their groups of speakers can rely on kin state protection. Because of their minimal or even negligible numbers and the lack of a protective power they play a marginal role in society. Almost as a rule, their sociocultural and sociopolitical influence at the state level is limited. Consequently, in most cases they lack the potential to become a decisive factor at the political level. One is tempted to say that even the integrative aspect of the European view of linguistic diversity is politically motivated.

\section{Emancipation of Minority Languages}

As indicated, the official recognition of a language is usually initiated by its speakers. Their status as an ethnolinguistic minority of a state typically results from an emancipatory process. The question remains, how are minorities integrated and how do they achieve integration. In principle both sides, minorities and states, pursue a strategy of differentiation.

From a majority perspective, another ethnicity has often been considered as a deviation from the norm. Thus, it has been sanctioned by exclusion and even stronger measures. As members of indigenous minorities are integrated as bilinguals today, total exclusion belongs to the past. Nevertheless, from the state level perspective as well as from the perspective of the majority population, indigenous ethnolinguistic minorities are always defined as different. Even in a majority's patronising mode of political correctness, difference is an underlying criterion in the commitment for a minority. 
Among individuals of the majority population, knowledge about an indigenous minority is often limited to the inhabitants and neighbours of the respective ethnically mixed regions of a state. If at all, members of the majority population perceive the members of an indigenous ethnolinguistic group as people that use another language among each other. Depending on the degree of closeness of the social contacts between minority and majority, the latter also may know about specific customs and traditions of the minority. Majority members tend to contrast the customs of a minority with their own. It is this contrast and the other language that constitute a minority group from the perspective of an individual of the majority population. Again, the main criterion of definition is difference.

The main emancipatory aim of an ethnolinguistic minority is official recognition by the state they live in. Emancipation always starts with selforganisation and self-definition. The main attributes of self-definition are a common cultural heritage and a common language. Both heritage and language are defined as different from those of the majority population. On the basis of these differentiating features, the minority perceives itself as an own people different from the majority. Many definitions include a historical presence on a certain territory of the respective state. Thus, the self-definition contains all the ingredients that constitute a nation: a people living on a certain territory with a common heritage and their own language. Consequently, the emancipation of ethnolinguistic groups is based upon the holy trinity.

The territorial definition of a minority language is especially problematic from the point of view of the majority. Territorial integrity is so to speak inviolable from the perspective of a state. In an ethnic nation-state the emancipation of an ethnolinguistic minority on the basis of the selfdefinition as a people with a traditional area of living in the territory of this state, is a contradiction in itself. In other forms of government the recognition and integration of groups that differentiate themselves from the statenation as, in a manner of speaking, their own nation can be achieved by the principle of ethnolinguistic autonomy.

Significant parts of the territory of the Soviet Union and its successor state, the Russian Federation have autonomous status. They are distinguished according to the administrative structure of republics, oblasts, and okrugs. 
- In the Sakha Republic of Yakutia in the Northeast of Siberia around 450,000 people, i. e. roughly $50 \%$ of the population, speak Sakha/Yakuts, a Turkic language. Among the other recognised languages are Even and Evenki, both Tungusic languages and Yukagir. The dominant language is Russian.

- In the Khanty-Mansi Autonomous Okrug or Yugra, the two eponymous Ob-Ugric languages are spoken by approx. 10,000 speakers each. Another Uralic language, the Samoyedic Nenets is also spoken on the territory. The dominant language is Russian.

- The Jewish Autonomous Oblast is located in the Russian Far East in the border region to Manchuria. It was founded in 1934 on the basis of the Soviet nationality policy to allow each people to pursue its cultural heritage. In 1948 about $25 \%$ or 30,000 people living in the Oblast were ethnic Jews. Nowadays less than 1\% have Jewish roots. By far the majority of the 175,000 inhabitants are Russian. But there are still language courses in Yiddish at the Birobidzhan Jewish National University.

To my knowledge, this is the only autonomous oblast of the Soviet period in the Russian Federation. This example indicates that territorial autonomy is not always a good solution to develop a people's cultural heritage. Especially if there is no traditional historical presence on a territory. Traditional presence applies to the autonomous territories of China.

- The Inner Mongolia Autonomous Region is populated by 20 million Han Chinese that amount to $80 \%$ percent of the population. With around $17 \%$, the Mongolian peoples are a minority of approximately 2,4 million. Besides Mongolian proper, there are small communities of Burjat, Oirat, and Dagur speakers. Other notable groups speak Ewenki, a Tungusic language, and Korean. Less than $2 \%$ or $0,5 \mathrm{M}$ inhabitants of the autonomous region are Manchu that have undergone language shift from their Tungusic language to Mandarin.

- The Tibet Autonomous Region of Xizang is inhabited by more than 2,8 million Tibetans that amount to 90\%. Approximately 250,000 or $8 \%$ of the population are Han Chinese. Furthermore, 
there are a few numerically smaller groups like the Monpa that are ethnolinguistically quite heterogeneous.

- The Uyghur Autonomous Region of Xinjiang is named after the roughly 10 million Turkic Uyghurs that amount to $45 \%$ of the population. Among the other groups are speakers of Mongolian languages, and of Kyrghyz and Kazakh. With more than 40\% Han Chinese are the second largest group. The region is subdivided into a multiplicity of autonomous prefectures and counties.

- The Guangxi Zhuang Autonomous Region is ethnolinguistically quite diverse. Roughly 15 million Zhuang people (32\%) speak Tai languages. With $62 \%$, the majority is Han Chinese. Guangxi is, among others, the homeland of Miao and Yao and the Dong minority that speaks a Kam-Sui language. Kam-Sui and Tai are branches of the Tai-Kadai language family. Hmong-Mien respectively Mia-Yao is another independent language family. The 0,4 million Miao, together with the 3 million Yao and the 0,3 million Dong amount to less than $5 \%$ of the population of the autonomous region.

The fifth region of Ningxia or the Hui Autonomous Region is irrelevant in the present context. The Hui are Mandarin-speaking Muslims with no other significant differences compared to Han Chinese. Not only the eponymous but all ethnic groups of these regions enjoy a certain protection as nationalities of the People's Republic of China. What the regions lack compared to others like the Sakha Republic is political and economic independence within certain limits. The Chinese version of autonomy rules out any weakening of central control over internal political matters and the natural resources of a region. By comparison, the Sakha Republic receives a good share of the returns from the territory's resources. Russian autonomy also allows its territories independent decisions within certain limits. For example, language education and the associated allocation of funds is in the responsibility of the Sakha Republic.

Other successful developments in the context of ethnic autonomy worth mentioning are the land claims of indigenous peoples of Canada.

- Nunatsiavut is an autonomous area in Newfoundland and Labrador. The main objective of the autonomy is the preservation of 
the Inuit cultural heritage and the environment. The population counts 2,000 people. Their language is Inuttitut.

- Nunavut is the largest, northernmost, and newest territory of Canada with a population of more than 32,000 and four official languages: $70 \%$ of the population speak Inuktitut, 27\% English, 1,3\% French, 1\% speaks Inuinnaqtun as a first language. Bilingualism in English is widespread. However, there are 2,300 (= $7,5 \%$ ) monolingual speakers of Inuit languages.

- The Northwest Territories are the most populous region in the North of Canada with roughly 41,000 inhabitants, which results in a density of $0.04 / \mathrm{km}^{2}$. The territory has eleven official languages: English, French, Cree, which is an Algonquian language, five Athabaskan languages (Chipewyan, Gwich 'in, North Slavey, South Slavey, Tlinchon) and three Inuit languages (Inuinnaqtun, Inuktitut, Inuvialuktun). $78 \%$ of the inhabitants speak English as a first language with the numbers for indigenous languages ranging from $\sim 2,000$ speakers of Tlinchon (less than 5\%) to 50 speakers of Inuinnaqtun (0,1\%).

Autonomy in the Canadian context is not merely limited to the ecological aspect of cultural preservation it also includes self-administration and the economical aspect of partial control of natural resources in the territory. Thus, autonomy also provides the necessary financial resources that enable a native community to live a self-determined life and, if the people so wish, to preserve their language and culture.

Another country that uses the concept of autonomy for the recognition of its ethnolinguistic communities is the Kingdom of Spain. In its original ratification document Spain declares the regional or minority languages protected under the Charter as

the languages recognised as official languages in the Statutes of Autonomy of the Autonomous Communities of the Basque Country, Catalonia, Balearic Islands, Galicia, Valencia and Navarra.

This definition applies to Basque, Catalan and Galician. The territories listed in the ratification have, among others, exclusive autonomy in the field of education, partial autonomy in cultural matters, and a significant 
control over financial expenses. This political set-up enables the autonomy governments not only to take measures to preserve the cultural heritage, but also to emancipate their languages and establish them in public formal domains.

The Autonomous Communities of the Basque Country, Catalonia, and Galicia are the so-called three "historical nationalities" in the Kingdom of Spain. Nationality is an ambiguous term ranging from the relation between an individual and their state to the designation of a group of people with a common heritage but without a state. It is the latter feature that differentiates nationalities from nations. However, this difference is often neglected. In many cases ethnolinguistic minorities declare themselves as nations and are sometimes identified and recognised as such by the respective majority population:

- Except for Inuit and Métis, the native peoples of Canada are collectively referred to as first nations.

- The Cherokee nation declared its language official on the Cherokee Nation Tribal Jurisdiction Area of Oklahoma.

- The definition of a nation plays a decisive role in the emancipation movement of the Maori in New Zealand.

- Many of the Uyghurs of Xinjiang consider themselves as a nation.

- The Sakha people has its own republic, language, national flag, national anthem, and other ingredients of a nation.

In principle, the declaration as a nation supports an ethnolinguistic group's emancipation from the state-nation and its dominant language. On the other hand, this emancipation pattern always implies and facilitates nationalism. Nationalism is not negative per se. Awareness and pride of the own group's cultural heritage and history is a common phenomenon. But nationalism always turns negative in combination with demands for homogeneity and aspirations of exclusiveness and superiority.

The languages of the three historical nationalities of Spain are at the upper end of the bandwidth of European minority languages. On the lower end of this scale is Romani, a non-territorial and stateless language with communities in all countries of Europe and beyond.

The Romani emancipatory movement developed into the International Romani Union in the late 1970s. 
- In the context of the Fourth World Romani Congress in 1990 culture and language became a main issue and the basic pre-requisite of the political movement. The International Day of the Roma was officially declared as April 8, in honour of the first World Romani Meeting in 1971.

- The Fifth World Romani Congress in 2000 produced a Declaration of Nation that claimed a non-territorial nation status for the Romani population of Europe.

- The Sixth World Romani Congress in 2004 established the World Parliament of the International Romani Union.

- The Seventh World Romani Congress in 2008 released The Roma Nation Building Action Plan. Among others, this plan aims for the establishment of a framework for the standardisation of $\mathrm{Ro}$ mani and the preservation of native dialects. This document also outlines plans for the development of Romani representation and nationalism.

Aside of the innovative declaration as a non-territorial nation, the outlined process fully complies with the general road map of European ethnolinguistic groups in their political endeavours for recognition. This road map consists of three steps:

- self-organisation, in the case of the Roma at national and supranational levels,

- self-definition on the basis of a common cultural heritage and language,

- self-attribution of the status of a nation and setting up of accompanying structures.

In the course of the declaration as a nation, the flag and the anthem of the Romani people turn into symbols of the Roma nation.

But it is not symbolism that matters, it is the self-definition that counts. For most ethnolinguistic groups, it is crucial to define their culture and language as different from the others. The emphasis on differences is a main characteristic in the argumentation for recognition and protection. Features of self-definition are often contrasted with those of others. The difference between the own and the other is the key factor of selfdefinition of an ethnolinguistic minority. Consequently, minorities rely on 
the same underlying strategy in their differentiation from the majority, as nation states in their mutual differentiation from each other: different people, different cultural heritage, different language, and different territory. Although the criterion of territoriality is excluded in special cases and less applicable to a few others, the self definition of ethnolinguistic minorities follows the principle of the holy trinity and the tribal concept of the difference between the own and the other.

Nevertheless, minorities are not to blame at all for adhering to this model of emancipation. To conform to the given patterns of differentiation of the majority is the best option they have. Thus, the emancipatory process of ethnolinguistic minorities may be characterised as organisational mimicry whereby the dominated replicate the structures and patterns of the dominant. As replication also includes the self-attribution of the status of a nation in the various contexts outlined so far, we end up with four types of ethnolinguistic nations:

- a state-nation,

- a nation within a state-nation,

- a fraction of a state-nation on the territory of another state-nation,

- a nation spread over the territories of other nations (= a nonterritorial nation).

\section{From Singularities to Plurality}

Against this background, Europe's cultural heritage is the juxtaposition of ethnonational singularities that are supposed to form a whole. European linguistic diversity is characterised as a multiplicity of ethnolinguistic differences that manifests itself as a conglomerate of languages. Some of these languages have the position of a state language. Many of the others have a legal status. Most of the legally recognised languages are additionally protected at the supranational level of the Council of Europe. The European view of linguistic diversity is so to say enshrined in the Council of Europe's instruments for the protection of national minorities and regional or minority languages. Although they are most probably the best instruments for minority protection, they have their limitations. They 
reflect only the least common denominator that was reached among European nation-states during a time window when diversity and integration were high on the political agenda.

The outlined scenario of cultural heritage and linguistic diversity also applies to the non-European countries mentioned so far. China has taken over a modified version of Soviet nationality policy that is fully in line with the European concept of difference. Canada, the United States and New Zealand are civic nation-states in the European tradition. They have only recently started to treat their indigenous peoples as equal citizens.

Difference is the primary constituent of European linguistic diversity. Its secondary constituent feature is dominance. It goes without mentioning that official languages at the state level dominate all other languages in a country. But power relations also shape the relationship between the other languages. Castilian as the official language of Spain, Catalan as co-official language in Catalonia, and Aranese as an official minority language in the Val d'Aran in the northwest of Catalonia constitute an exceptional case of a legally regulated hierarchy of dominance. Power relations between ethnolinguistic groups often follow the lines of relative size, degree of organisation, and political influence. The smaller in number and the weaker in representation, the less influence and the more dominated by others. The role of biased attitudes and hidden hierarchies in such power relations can only be mentioned here.

Another obvious result of dominance is the monolingualism of majorities and the bilingualism of minorities. Power relations furthermore shape cross-border bilingualism. The idealised reciprocal situation in the Danish-German border region mentioned earlier has to be seen as exceptional. Almost as a rule, cross-border bilingualism is imbalanced.

The power relations of the Austro-Hungarian Empire in combination with the current economic situation of Austria determine the ethnolinguistic relations with its eastern neighbours. Czech, Slovak, Hungarian and Slovene are recognised minority languages as well as official languages in neighbouring countries. However, there is only individual bilingualism among the German-speaking majority on the Austrian side of the border. There are sufficient opportunities to learn these languages and the educational system would be flexible enough to deal with increasing demand. 
But the offer is only accepted in individual cases and in the context of a few special projects that are usually strongly promoted. Just as for centuries, German-speaking Austrians expect their neighbours to have a knowledge of German. It remains the case that cross-border bilingualism among the Slavic and Hungarian neighbours is more common. A lot of responsible parents make use of Austrian schools to improve their children's opportunities in life by learning in another language.

As a rule, issues of dominance also characterise the relationships between kin states, the ethnolinguistic groups they protect, and the states in which these minorities live. Such protective measures may be perceived as interference in a state's internal affairs. Consequently, they have the potential to result in open conflicts as in the so-called separatist regions of Georgia, Moldova, and Ukraine.

Dominance and difference, furthermore, result in the exclusion of languages of migrants from the linguistic diversity of Europe. Even in cases where many members of a migrant community are citizens of the country of immigration their languages have no legal status. As "languages of migrants" they are explicitly excluded from the protection under the Charter. On the basis of indigenousness, the languages spoken in Europe are distinguished into autochthonous and allochthonous. The autochthonous languages account for the linguistic diversity, the allochthonous are labelled foreign and are perceived as non-European.

Against the background of this outline description, European linguistic diversity has to be characterised as

- exclusive and excluding,

- ruled by the principles of dominance and difference,

- based upon the holy trinity, the link between a people, its territory, and its language.

Since biblical times, sociopolitical development in the view of language has been stuck in the tribal dichotomy between the own and the other. The link between a kin group and its language on a tribal territory has changed into the link between a nation and its language on the territory of a state. Further development linked territoriality with ethnolinguistic diversity at both the national and the supranational level. But dominance and difference still limit the linguistic diversity of Europe to an exclusive hierarchy of indigenous languages. The linguistic landscape of Europe may be 
compared to a patchwork made of differently sized elements with a lot of holes that symbolise the excluded languages. What is missing to include all languages of Europe is a clear commitment to plurality as a concept of multiplicity without fundamental differentiation.

In his essay on Language Policy and National Unity in South Africa, the late Neville Alexander raised some basic questions that might be a starting point for the development towards linguistic equality.

Is it true that a language group is the same thing as a nation or a cultural group?

Is it true that for people to be a nation they all have to speak the same language?

Is it true that every language is the bearer of a unique culture?

Are these views, which are seen as common sense in most parts of the world, founded on indisputable facts?

(Alexander 1989: 47)

The simple answer to all these questions is no. However, from the current position it seems to be impossible to establish this insight on the political level and at the same time in the European subconscious. It might be easier to start with the integration of all languages in the context of functional plurality.

If people cannot speak to one another they cannot constitute a nation. The crucial question, however, is whether they have to speak to one another in a particular language in order to be a nation. ... All that is necessary is that they be able to switch to the most appropriate language demanded by a particular situation.

A focus on the functionality of languages could help to reduce the importance of both the language-territory and the language-ethnicity link. Plurality of languages with a complementary distribution that is not valued on the basis of difference and dominance but on the basis of functionality and equality might be a starting point to overcome the tribal concept of the own and the other. If this becomes possible in the future, the development of the ideology of the nation-state summarised above could be extended by a projection into the $21^{\text {st }}$ century: 
- the $18^{\text {th }}$ century sees its development,

- the $19^{\text {th }}$ century sees its implementation,

- the 20 $0^{\text {th }}$ century sees its perversion and its democratic transformation, and

- the $21^{\text {st }}$ century sees the deconstruction of the ideology by the concept of plurality?

\title{
References:
}

Alexander, Neville. 1989. Language policy and national unity in South Africa/Azania. Cape Town: Buchu Books.

Anderson, Benedict. 1983. Imagined communities. London: Verso Publications.

Fishman, Joshua A. 1972. Language and nationalism: two integrative essays. Rowley/Mass.: Newbury House.

Fishman, Joshua A. 1989. Language and ethnicity in a minority sociolinguistic perspective. Clevedon: Multilingual Matters.

\begin{abstract}
Minority politics and resulting minority language policies are based upon the European ideology of the nation-state and the state-nation; a concept that results from the tribal dichotomy between the own and the other which is interpreted as homogeneity between a people, its territory, and its culture. The latter is, first of all, symbolized by a common language. Consequently, minorities are perceived as different by the respective majority. On the other hand, this alienation results in the self-perception of a minority as another nation with another language dominated by a state-nation with a dominant language. Against this background European linguistic diversity has to be characterized as excluding, and ruled by the principle of dominance. However, this homogeneity claiming and difference stressing sociopolitical approach contradicts the pluralistic reality of human culture. Thus, policies and measures to protect ethnolinguistic diversity have to be based on an ideology or rather politics of plurality.
\end{abstract}

Keywords: minority language policy, nation-state and state-nation European ideology; principle of dominance and homogeneity vs. politics of plurality. 


\section{Bibliographical statement}

DIETER W. HALWACHS: Sociolinguist at the University of Graz; head of the Plurilingualism Research Unit at the University's language centre treffpunkt sprachen; member of the Committee of Experts of the European Charter for Regional or Minority Languages at the Council of Europe; coordinator of various projects on minority languages and cultures, first of all Romani; research interests: language politics, minority linguistics, endangered languages, language contact, etc.

E-mail: dieter.halwachs@uni-graz.at 